\title{
Water repellency in eucalyptus and pine plantation forest soils and its relation to groundwater levels estimated with multi-temporal modeling
}

\author{
H.I.G.S. Piyaruwan ${ }^{1}$, P.K.S.C. Jayasinghe ${ }^{2}$, D.A.L. Leelamanie ${ }^{1 *}$ \\ ${ }^{1}$ Department of Soil Science, Faculty of Agriculture, University of Ruhuna, Mapalana, Kamburupitiya 81100, Sri Lanka. \\ 2 Department of Information and Communication Technology, Faculty of Technology, University of Ruhuna, Karagoda-Uyangoda, Kam- \\ burupitiya 81100 , Sri Lanka. \\ * Corresponding author. Tel.: +94-71-861-4380. Fax: +94-41-2292384. E-mails: leelamanie@soil.ruh.ac.lk; leelamaniee@yahoo.co.uk
}

\begin{abstract}
Water repellency makes soils capable of resisting to the penetration of water applied on the surface and inflict various influences on groundwater. The objectives of the present study were to identify the water repellency under pine and eucalyptus plantations, to determine social impacts of water level changes, to find possible changes in groundwater levels in the surrounding areas during the past four decades, and to relate water repellent characteristics of soils with the groundwater level changes. The study was conducted in eucalyptus (Eucalyptus grandis) and pine (Pinus caribaea) plantation forests located in Upcountry intermediate zone, Sri Lanka. Each land was separated into three blocks (B1, B2, B3) based on the slope. Water repellency was measured with water drop penetration time (WDPT) and contact angle. The water entry value was estimated with the pressure head method. Interconnected social impacts was examined using a questionnaire based survey. Groundwater levels from 1980 to present were modeled with remotely sensed information. Both eucalyptus and pine forest soils showed water repellency, which decreased with increasing soil depth. Eucalyptus soils showed highly hydrophobic conditions on the surface (WDPT>7200 s). Ponding depths required for entry of water into the soil in eucalyptus soils was $4.6-5.3 \mathrm{~cm}$, whereas that of pine soils was $1.5-4.0 \mathrm{~cm}$, although achieving these levels would be difficult considering the steep slopes. Contact angle showed positive logarithmic correlation with water entry value. The people living in the surrounding areas expressed less water availability for their domestic purposes, decreased water level in household wells, and drying up of natural water resources at present compared with 1980s. Modelling with remotely sensed thematic maps confirmed that the groundwater levels in both areas has decreased over the time. It indicated that the eucalyptus and pine vegetation have created unfavorable conditions in regard with water entry and groundwater recharge. Proper attention from the responsible authorities will be essential to prevent the adverse impacts of on groundwater resources.
\end{abstract}

Keywords: Eucalyptus grandis; Groundwater modeling; Pinus caribaea; Water repellency; Water entry value.

\section{INTRODUCTION}

Soil water repellency (SWR) is a phenomenon that make soils capable of resisting to the penetration of water applied on the surface. It is caused by organic compounds containing hydrophobic properties that are coating individual soil particles, or present in soil as interstitial matter. These hydrophobic molecules are released at natural conditions, during fires from plants, organisms, and decomposing organic matter in soils. Water repellent coatings also can restrict the interactions between pores inside and outside of the soil aggregates (Fér et al., 2016). SWR lessens the affinity of soils towards water to different degrees, resisting the wetting for durations that may range from a few seconds to hours or days (Doerr and Thomas, 2000). It influences important hydrological and geomorphological consequences such as lowered infiltration rates, upsurge of the overland flow, uneven wetting, development of preferential fingerlike and bypass flows (Imeson et al., 1992; Kobayashi and Shimizu, 2007). SWR decreases the capacity of infiltration in soil and enhances runoff events specially in steep slope lands during the early stages of rainfall (Contreras et al., 2008; Siteur et al., 2016). In addition, organic-clay coatings on soil aggregates in some soils may influence water and solute transport into soil aggregates (Fér and Kodešová, 2012; Gerke and Köhne, 2002).

Occurrence of SWR has been reported in diverse natural climatic and weather conditions, soil types and vegetation cover of large trees to small turf grasses. Forests with water repellent conditions have been recognized to alter the hydraulic properties of soils (Kajiura et al., 2012; Kobayashi and Shimizu, 2007; Leelamanie and Nishiwaki, 2019; Lichner et al., 2013; Wahl et al., 2003). Various kinds of impacts of SWR on the soil water systems have been characterized by several studies under different land uses, climatic conditions, and regions. Water repellency is frequently found in soils covered by tree species such as Eucalyptus (Eucalyptus globulus), Cluster pine (Pinus pinaster), Scots pine (Pinus sylvestris), Cypress (Chamaecyparis obtusa), Japanese cedar (Cryptomeria japonica), and Casuarina (Casuarina equisetifolia) (Alagna et al., 2017; Benito et al., 2019; Iovino et al., 2018; Kobayashi and Shimizu, 2007; Leelamanie, 2016; Leelamanie and Nishiwaki, 2019; Lichner et al., 2013). The SWR observed in conifer forests is considered to be a natural characteristic rather than being induced by external factors such as forest fires (Doerr et al., 2009). Water repellency is known to influence groundwater in different ways. It induces preferential flow paths that provide shortened and faster routes for the transport of water and solutes, accelerating the driving of solutes to the groundwater increasing the risk of groundwater pollution (Bauters et al., 1998; Ziogas et al., 2005). Eucalyptus and pine plantations in Sri Lanka, which show water repellent conditions (Leelamanie et al., 2016), are getting increasing attention at present due to the social uneasiness on lowering the availability of water resources related to the establishment of these exotic species. 
Groundwater is one of the most important natural resources on the earth that supports the ecological diversity and human health (Rao et al., 2001). Falling of groundwater tables are reported at remarkable rates in most parts of the world (Giordano, 2009). Decline of groundwater level causes numerous eco-environmental problems such as oasis degeneration, drying up of wetlands, disappearance of streams and artesian wells, and salt water intrusions etc. The recharge of groundwater depends mainly on several factors such as infiltration capacity and permeability, stochastic characteristics of rainfall, and other climatic factors. In arid regions, recharge of groundwater occurs mainly through ephemeral streams. In semiarid regions, the recharge of groundwater is mostly irregular and occurs in the periods of heavy rainfall (Şen, 2015). With above $1800 \mathrm{~mm}$ of average annual rainfall (Zubair and Ropelewski, 2006) the main natural groundwater recharge in Sri Lanka is by the precipitation as rainfall. In general, upland areas are considered to be the sources for groundwater recharge or replenishment, and lowland areas are considered to be the points of discharge. In recent decades, the natural systems of groundwater recharge and discharge in many regions of the world are found to be critically altered by various human activities (Giordano, 2009). Groundwater table diminishes when the rate of recharge is lower than the rate of withdrawal (Senanayake et al., 2016). It is clear that low rates of replenishment or high rates of withdrawal may lead to depletion of groundwater table, leading to dropped water level in groundwater wells as well as in surface water resources such as lakes and streams.

Remote sensing and Geographical Information System (GIS) play an important role in the management of water and land resources. GIS technique can be used as an efficient tool in identification of groundwater levels in different locations. Remote sensing can be effectively used to acquire surface feature information related to groundwater such as land use, land forms, and drainage and to handle widespread data for modeling (Brunner et al., 2007). Standardizing the low reflectance in red band and higher reflectance in infrared band, it is possible to measure various vegetation-related features using normalized difference vegetation index (NDVI) (Pan et al., 2008). Modelling techniques use remotely sensed data with surface reflectance to relate surface soil moisture to the shallow groundwater level. The relationship of the surface reflectance and the depth to the groundwater level can be assessed with the observation of groundwater wells (Pan et al., 2008).

Only limited reports are available to understand the influence of repellency-induced changes to the groundwater levels. Adane et al. (2017) recently reported that the presence of water repellent conditions reduced groundwater recharge, which is caused by the combinations of increased extraction of water by plants and the declined infiltration rates due to water repellent surface layer. Still, the hydrological alterations caused by soil water repellent conditions and their multi-temporal consequences on groundwater dynamics have received comparatively a less attention. Present study was planned with the four main purposes: to identify the SWR under pine and eucalyptus plantations; to determine the social impacts of water level changes using a questionnaire based survey; to find the possible changes in groundwater levels in the surrounding areas of pine and eucalyptus plantations during the past four decades; and to relate the water repellent characteristics of the soils with the groundwater level changes of the areas.

\section{MATERIALS AND METHODS}

Study sites and soil sampling

The experimental site one (S1) was a eucalyptus (Eucalyptus grandis) plantation forest in Diyathalawa with an area of around 100 ha, located in the Upcountry intermediate zone (IU3c agro ecological region) of Sri Lanka (National Atlas of Sri Lanka, 2007). The mean annual rainfall is above $1700 \mathrm{~mm}$. The second experimental site (S2) was a pine (Pinus caribaea) plantation forest in Haputale with an area of around 5 ha, which was also located in the Upcountry intermediate zone. The area belongs to the IU3a and IU3b agro ecological regions with annual precipitation of $1700-1900 \mathrm{~mm}$. The road distance between the two study sites is around $11 \mathrm{~km}$ (the areal distance $\sim 5-6 \mathrm{~km}$ ). In the both sites, the largest rainfall events are in between December to February and the mean annual temperature is in the range of $20-22.5^{\circ} \mathrm{C}$. The soils of the two sites are of a sandy loam texture and classified as red yellow podzolic soils under local classification and Hapludults under USDA classification (Soil Survey Staff, 2014).

Three sampling blocks (B1, B2, and B3) were selected from each site based on the slope of the experimental site, where B3 was selected to be on the top of the hill in both sites. The distances between the blocks were kept around 100-150 m. Table 1 shows the coordinates of the three soil blocks and slopes of the two sites. Core samples (undisturbed: for measurement of bulk density) and the bulk samples (disturbed) were collected from the blocks at the depths of $0-5,5-10$, and $10-15 \mathrm{~cm}$ in three replicates for each depth, in years of 2017 and 2018, in wet season (November to February). The collected samples were transported to the laboratory in labeled and sealed polythene containers.

Table 1. Sampling locations and land slopes in eucalyptus and pine plantation forests.

\begin{tabular}{|c|c|c|c|}
\hline Soil Block & $\mathrm{N}$ & $\mathrm{E}$ & Slope $\left({ }^{\circ}\right)$ \\
\hline \multicolumn{4}{|c|}{ Eucalyptus } \\
\hline B1 & $06^{\circ} 47^{\prime} 42^{\prime \prime}$ & $080^{\circ} 57^{\prime} 57^{\prime \prime}$ & 10.4 \\
\hline B2 & $06^{\circ} 47^{\prime} 45^{\prime \prime}$ & $080^{\circ} 57^{\prime} 58^{\prime \prime}$ & 20.3 \\
\hline B3 & $06^{\circ} 47^{\prime} 56^{\prime \prime}$ & $080^{\circ} 57^{\prime} 43^{\prime \prime}$ & 34.4 \\
\hline \multicolumn{4}{|l|}{ Pine } \\
\hline B1 & $06^{\circ} 46^{\prime} 15^{\prime \prime}$ & $080^{\circ} 55^{\prime} 50^{\prime \prime}$ & 11.4 \\
\hline B2 & $06^{\circ} 46^{\prime} 13^{\prime \prime}$ & $080^{\circ} 55^{\prime} 52^{\prime \prime}$ & 24.8 \\
\hline B3 & $06^{\circ} 46^{\prime} 13^{\prime \prime}$ & $080^{\circ} 55^{\prime} 50^{\prime \prime}$ & 41.5 \\
\hline
\end{tabular}

\section{Laboratory measurements}

The samples were air dried at room temperature $\left(27 \pm 3^{\circ} \mathrm{C}\right)$, and $75 \pm 5 \%$ relative humidity, for 3 days. Samples were passed through a $2 \mathrm{~mm}$ mesh to eliminate the coarse particles before the soil testing. The persistence and the degree of water repellency was measured using the water drop penetration time (WDPT) and soil-water contact angle, respectively. The critical point of water-entry into the soil was measured using the water entry value (Wang et al., 2000) of the samples. Bulk density (Undisturbed core method; Blake and Hartge, 1986a), particle density (Pycnometer method; Blake and Hartge, 1986b), Porosity (numerical method), Texture (Hydrometer method; Bouyoucos, 1962) and OM\% (Loss on ignition method; Schumacher, 2002) were determined all soil depths for both sites. The measurements were conducted in in three replicates, in the laboratory with air-dried samples. 


\section{The WDPT test}

Soil samples were placed in porcelain containers with a sample thickness of $>5 \mathrm{~mm}$ to avoid interferences of drops reaching the bottom of the containers. A burette was filled with distilled water and one drop $(50 \pm 1 \mu \mathrm{l})$ of distilled water was carefully placed on the soil surface from a height of about 10 $\mathrm{mm}$ to minimize the collision impacts by the falling drops. The volume of the droplet was set to $50 \mu \mathrm{l}$ to represent the average size of a raindrop. Containers were covered with lids to minimize the evaporation during the experimental period. The time taken for water drop to complete the penetration was measured using a stop watch (Leelamanie et al., 2008). Penetration times shorter than $0.5 \mathrm{~s}$ were considered as $0 \mathrm{~s}$, because the actual measurement could not be taken accurately corresponding to the instantaneous penetration. The measurement of penetration time was terminated after $7200 \mathrm{~s}$ and all WDPTs exceeding 7200 s were assigned to be $7200 \mathrm{~s}$. The WDPT values were determined in six replicates for each soil depth in the three blocks in both sites.

\section{Soil-water contact angle}

The Soil-water contact angle was measured using the modified sessile drop method (SDM) (Bachmann et al., 2000), in six replicates, using a digital microscopic camera (FS-3100-PC, Fujikoden Co. Ltd., Japan). Monolayers of soil samples was prepared by sprinkling the air dried and sieved soil samples on a double-sided adhesive tape $(1.5 \mathrm{~cm} \times 1.5 \mathrm{~cm})$ fixed on smooth glass slides. Sprinkled soil was pressed to the tape using a $100 \mathrm{~g}$ weight for $10 \mathrm{~s}$ and the surplus soil was removed by gently tapping the glass slide. To ensure the stabilization of a soil monolayer on the adhesive tape, the same procedure was repeated twice. The slides with soil monolayers were placed on the stage of the digital microscopic camera. A drop of distilled water $(10 \mu \mathrm{L})$ was placed on the soil surface using a micro pipette (Nichipet EX II J15615241. Nichiriyo, Japan). Digital micro-photograph of the horizontal view of the water drop was taken within $1 \mathrm{~s}$. Contact angle of each sample was determined using the micro-photographs of the horizontal view of the drop on the soil monolayer (Leelamanie et al., 2008; Leelamanie, 2016), using the both points of contacts of the water to the soil layer in the two-dimensional photograph of the drop.

\section{Water entry value}

Low hydraulic pressures at the soil surface is not sufficient to make water infiltrate into water repellent soils. The critical pressure head that requires to the breakdown repellency and start the infiltration can be determined using the water entry value. The water entry values of the samples were tested for soils collected from the surface $(0-5 \mathrm{~cm})$ using the pressure head method (Wang et al., 2000). Air-dried 50-g soil samples were placed on the porous plate of a Buchner funnel, which was covered with a membrane filter mounted filter paper, and the funnel was connected to a burette by a flexible tube. A hydraulic pressure was applied to the soil by raising the burette level, starting from a negative pressure head to avoid initial wetting of the soil (Wang et al., 2000). The pressure was carefully increased by $5 \mathrm{~min}$ time intervals up to the point where the water enters the soil matrix. At the point of water entry, the height of the water column was measured with respect to the reference level considering the soil as the water entry values of the samples (Liyanage and Leelamanie, 2016).

\section{Groundwater modeling with remotely sensed information}

This method was used to determine the relations of the irregularities in recharge of groundwater in water repellent soils to the groundwater levels of the areas surrounding the study sites. The method depends on the fact that the soil moisture on the surface is related with the shallow groundwater level. As the reflectance of the land surface related to normalized difference vegetation index (NDVI) obtained from the remote sensing images varies with the surface soil moisture, a relationship between the reflectance obtained from the remote sensing images and groundwater level depth using the method by Pan et al. (2008).

The NDVI is related to the surface vegetation coverage, in regard with the quality or the density. The higher the density of vegetation, the larger the value of NDVI.

$N D V I=\left(R \mathrm{~s}_{2}-R s_{1}\right) /\left(R s_{2}+R s_{1}\right)$

where $R s_{1}$ and $R s_{2}$ are respectively the radiance of the band 1 (near infrared) and band 2 (red) in Landsat images (wave lengths: $0.63-0.67 \mu \mathrm{m}$ and $0.77-0.90 \mu \mathrm{m}$ for band 1 and 2 respectively). The temperature surface can be determined using the split window technique with thermal infrared band data.

$T_{S}=R s_{10}+a\left(R s_{10}-R s_{11}\right)+c$

$T_{S}$ denotes the surface temperature (Land surface temperature, LST), $R s_{10}, R s_{11}$ are the radiance of thermal bands 10 and 11 , respectively in Landsat images (wavelengths: 10.6-11.19 $\mu \mathrm{m}$ and $11.5-12.51 \mu \mathrm{m}$ for band 10 and 11 , respectively), a denotes the model parameter, and c denotes the split window coefficient. The soil moisture on the surface is described by using the LST and NDVI.

$M C_{\mathrm{S}}=f\left(T_{S}, N D V I\right)$

where $M C_{\mathrm{S}}$ is surface soil moisture content.

The depth level of shallow groundwater is related to the surface soil moisture, where the relationship between the groundwater level depth and the soil moisture is stated as follows

$M C_{S}=\alpha_{0}+C_{1} \exp \left(D_{W}\right)$

$D_{\mathrm{W}}$ is the depth of groundwater level. By combining Eq. (3) and (4), a mathematical model can be developed for the depth of groundwater level (Pan et al., 2008);

$D_{W}=k \times \ln \left(N D V I \times T_{S}\right)+b$

where $k$ and $b$ are the coefficients that can be achieved by curve fitting using the groundwater levels obtained by the observation of water levels of groundwater wells in the field. The field data on the water levels of groundwater wells situated surrounding both study areas ( 3 wells per study area) were gathered for consecutive period of six months to represent (Pan et al., 2008). The $N D V I$ and $T_{S}$ parameters were estimated through remote sensing images of the areas in same time period. Surface temperature and NDVI thematic maps for eucalyptus and pine plantation forest areas in 2018 are presented in Fig. 1 and Fig. 2 . Then the $D_{\mathrm{W}}$ values were plotted against the $\ln \left(N D V I \times T_{S}\right)$ to obtain a linear correlations and the $\mathrm{k}$ and $\mathrm{b}$ values were determined for the linear curves. Finally, these $\mathrm{k}$ and $\mathrm{b}$ coefficients can be used in the Eq. (5) with $N D V I$ and $T_{S}$ parameters estimated through remote sensing images in the areas in the 
(a)
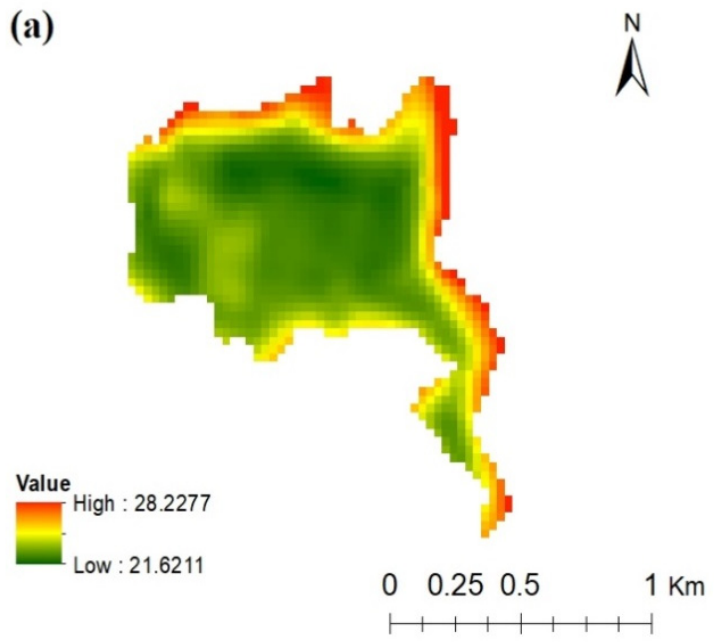

(b)

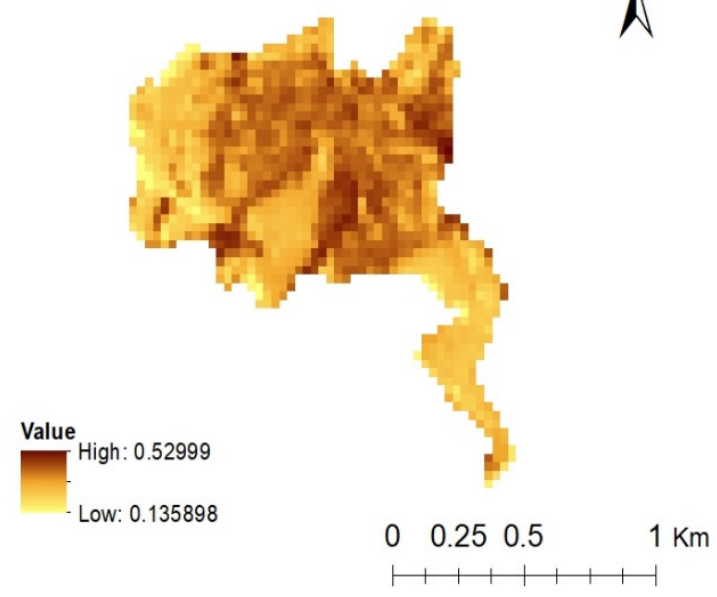

Fig. 1. Thematic maps of the land surface temperature (LST) and normalized difference vegetation index (NDVI) for eucalyptus plantation forest area in 2018 .

past. These estimated $\mathrm{k}$ and $\mathrm{b}$ values were used with $N D V I$ and $T_{S}$ parameter for the years of 1980, 1990, 2000, 2010 and 2018, to estimate depth to the groundwater level from surface in both Haputale (pine) and Diyathalawa (eucalyptus) areas.

Remote sensing mages were obtained from satellite sensors for 1980 (Landsat 5), 1990 (Landsat 5), 2000 (Landsat 7), 2010 (Landsat 7), and 2018 (Landsat 8). Pre-processing functions were performed for the satellite images before analyzing. Google earth application was used to extract the maps of the study areas (eucalyptus and pine plantation forests). These maps were used to subset the study areas from Landsat images. Thermal bands of the Landsat images were used to estimate the LST and NDVI through the raster image calculator in ArcMap tool (ESRI, 2017).

\section{Social impacts of SWR}

Questionnaire based survey was conducted in Haputale and Diyathalawa areas to relate onsite SWR of the studied sites to the hydrological consequences and interconnected social impacts. Forty persons from each area were selected randomly among the people living near (within a distance of $5 \mathrm{~km}$ to each site) to the respective pine and eucalyptus plantations for this (a)

$N$

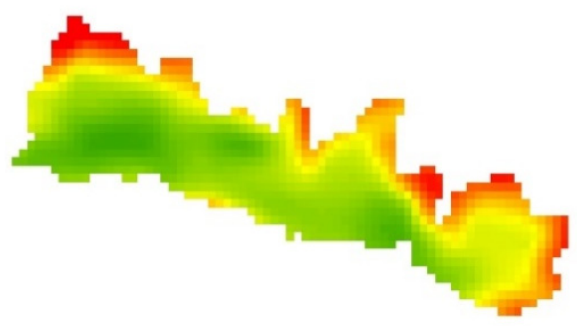

Value

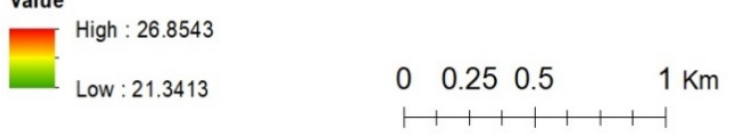

(b)

$N$

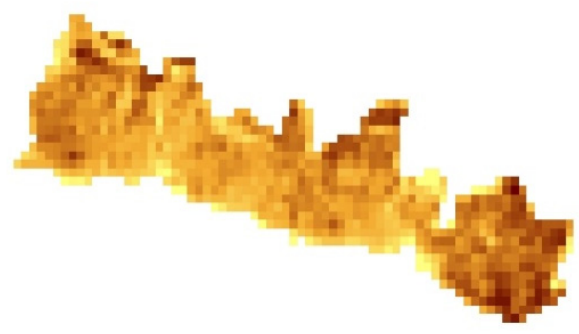

Value
- Low: 0.164844

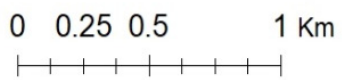

Fig. 2. Thematic maps of the land surface temperature (LST) and normalized difference vegetation index (NDVI) for pine plantation forest area in 2018.

survey. Questions were mainly focused to determine the impressions and opinion of the people in relation to the hydrological consequences, basically the water scarcity conditions comparing the past and present conditions. For the statistical analysis, the responses of people on the availability of water for their domestic purposes were separated into three categories as 'better', 'worse', and 'no change' and assigned 2, -2, and 0, respectively. The responses on the changes in water level in their household groundwater wells were also separated into three categories as 'increase', 'decrease', and 'no change' and assigned $2,-2$, and 0 , respectively. The responses of the people living in the Diyathalawa and Haputale areas on the drying up of proximate artesian wells and water resources were separated into two categories as 'yes' and 'no'.

\section{Data analysis}

The data were statistically analyzed with analysis of variance (ANOVA), regression analysis and correlation, at 0.05 probability level using Microsoft Excel 2013 data analysis tool pack. Results from questionnaire based survey was analyzed using non-parametric statistics with Wilcoxon sign rank test, where Minitab 17 software was used for the analysis. 


\section{RESULTS AND DISCUSSION Basic properties of soils}

Both soils showed comparatively high bulk densities (mostly $>1 \mathrm{~g} \mathrm{~cm}^{-3}$ ). The texture of soils in both sites in all the soil depths were sandy loam. Organic matter decreased with increasing depth of the soil profile in all three blocks in both study sites. Table 2 presents the information on the basic properties of the soils in the two study sites (three blocks, three depths) in detail.

\section{Presence of water repellency}

The persistence of water repellency in eucalyptus and pine plantation forest soils as measured by WDPT (log WDPT) is given in Fig. 3. In all the soil, the highest WDPT was found in the top soil layer $(0-5 \mathrm{~cm})$, decreased with the increasing soil depth. Surface soils in all three blocks of the eucalyptus forest were extremely water repellent with WDPT exceeding $7200 \mathrm{~s}$ (Fig. 3a). Pine forest soils showed lower repellency compared with that of eucalyptus except in the B3, which showed WDPT $>7200$ (Fig. 3b). Surface soils in B1 showed slight water repellency $(10 \mathrm{~s}<\mathrm{WDPT}<60 \mathrm{~s})$ and those of B2 showed severe water repellency $(600 \mathrm{~s}<\mathrm{WDPT}<3600 \mathrm{~s})$.

The degree of water repellency in eucalyptus and pine plantation forest soils as measured by soil-water contact angle is given in Fig. 4. Similar to the WDPT results, surface soils of both eucalyptus and pine forests showed the highest contact angle and decreased with increasing soil depth. Eucalyptus forest soils showed highly hydrophobic nature on the surface with soil-water contact angles in all the blocks exceeding $90^{\circ}$ (Fig. 4a). Pine forest soils showed comparatively low contact angles $\left(83-84^{\circ}\right)$ on the surface in B1 and B2, and similar to the WDPT results, very high contact angle in B3 $\left(100^{\circ}\right)$ (Fig. $\left.4 b\right)$.

Several contradictory reports are available to show the water repellency to be existing from the top down to the weathered horizon as well as to be increased with increasing soil depth (eg. Doerr et al., 1996; Santos et al., 2016). However, weakening of water repellency with increasing soil depth is more commonly reported in casuarina, pine, eucalyptus, and oak forest soils in most continents (Badia-Villas et al., 2014; FloresMangual et al., 2013; Leelamanie, 2016; Lichner et al., 2007; Rodriguez-Alleres et al., 2007). It was clear that the highest repellency of both eucalyptus and pine soils tested in this study
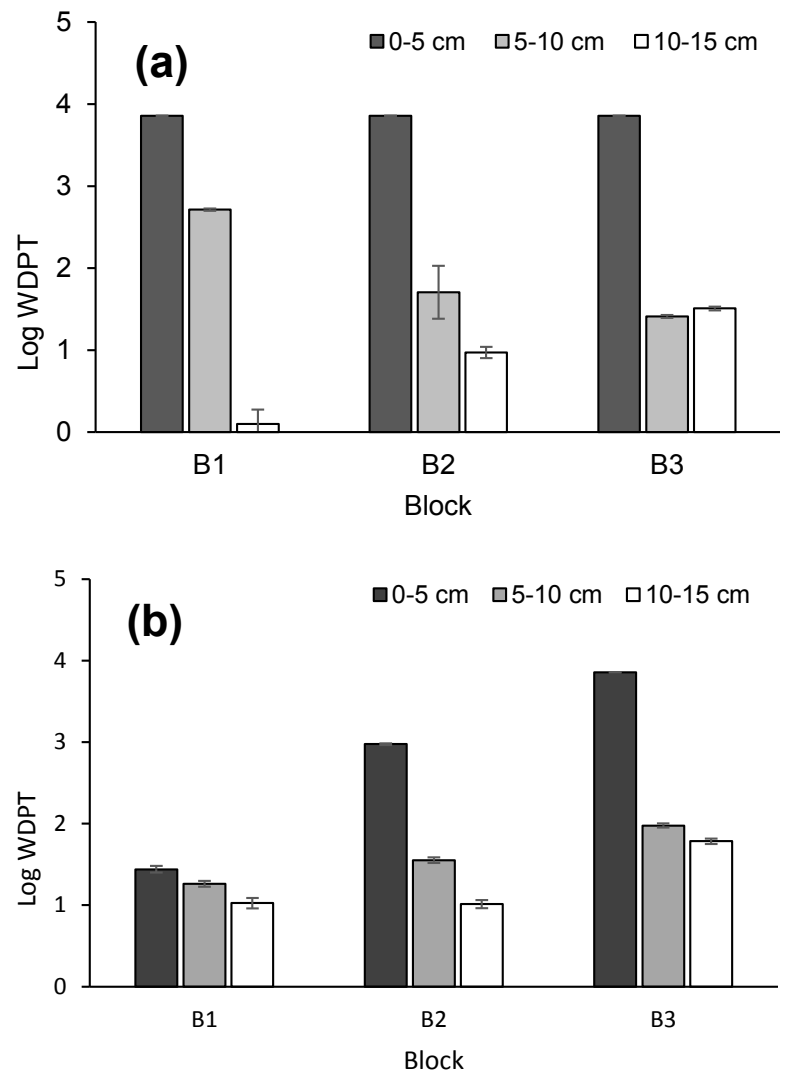

Fig. 3. The persistence of water repellency in eucalyptus and pine plantation forest soils as measured by WDPT (log WDPT).

confined to the surface layer revealing a diminishing water repellency with increasing depth of soil. According to numerous reports, soil water repellency is influenced by the content and the composition of organic matter. Mostly reported correlations between the organic matter content and SWR are positive, where the reductions in the SWR soil depth are generally attributed to the diminishing organic matter content (McKissock et al., 1998; Rodriguez-Alleres et al., 2007; Vogelmann et al., 2010; Wallis et al., 1990; Woche et al., 2005). Accordingly, the lowering of SWR towards deeper soil layers in the present study can be considered related to the declining of organic matter content.

Table 2. The basic properties of eucalyptus and pine plantation forest soils.

\begin{tabular}{lccccccccc}
\hline \multirow{2}{*}{ Soil property } & \multicolumn{4}{c}{ Block 01 } & \multicolumn{3}{c}{ Block 02 } & \multicolumn{2}{c}{ Block 03 } \\
\cline { 2 - 9 } & $0-5 \mathrm{~cm}$ & $5-10 \mathrm{~cm}$ & $10-15 \mathrm{~cm}$ & $0-5 \mathrm{~cm}$ & $5-10 \mathrm{~cm}$ & $10-15 \mathrm{~cm}$ & $0-5 \mathrm{~cm}$ & $5-10 \mathrm{~cm}$ & $10-15 \mathrm{~cm}$ \\
\hline Eucalyptus & & & & & & & & \\
Bulk density $\left(\mathrm{g} \mathrm{cm}^{-3}\right)$ & $1.03 \pm 0.10$ & $1.11 \pm 0.04$ & $1.20 \pm 0.01$ & $0.98 \pm 0.08$ & $1.04 \pm 0.11$ & $1.19 \pm 0.08$ & $1.02 \pm 0.06$ & $1.04 \pm 0.09$ & $1.04 \pm 0.04$ \\
Porosity (\%) & $53.5 \pm 7.1$ & $50.1 \pm 4.6$ & $48.8 \pm 2.9$ & $57.37 \pm 6.5$ & $58.6 \pm 2.3$ & $51.3 \pm 5.4$ & $57.0 \pm 2.7$ & $55.5 \pm 5.7$ & $55.0 \pm 3.6$ \\
Sand \% & $80.3 \pm 1.5$ & $74.4 \pm 0.1$ & $79.5 \pm 0.1$ & $82.1 \pm 0.1$ & $79.4 \pm 0.1$ & $76.7 \pm 0.2$ & $79.4 \pm 0$ & $71.6 \pm 0.1$ & $81.9 \pm 0.1$ \\
Silt \% & $6.9 \pm 1.5$ & $6.8 \pm 1.5$ & $4.3 \pm 1.5$ & $5.1 \pm 0$ & $6.9 \pm 1.5$ & $10.3 \pm 0.1$ & $3.4 \pm 1.5$ & $7.7 \pm 0$ & $2.6 \pm 0$ \\
Clay \% & $12.9 \pm 0$ & $18.8 \pm 1.4$ & $16.2 \pm 1.4$ & $12.8 \pm 0$ & $13.7 \pm 1.5$ & $12.9 \pm 0.1$ & $17.1 \pm 1.5$ & $20.6 \pm 0.1$ & $15.5 \pm 0$ \\
Organic matter (\%) & $9.93 \pm 0.12$ & $7.04 \pm 0.05$ & $6.88 \pm 0.04$ & $11.6 \pm 0.30$ & $7.71 \pm 0.08$ & $6.33 \pm 0.02$ & $9.19 \pm 0.17$ & $7.83 \pm 0.12$ & $6.75 \pm 0.03$ \\
& & & & & & & & & \\
Pine & & & & & & & \\
Bulk density (g cm $\left.{ }^{-3}\right)$ & $0.93 \pm 0.05$ & $1.03 \pm 0.08$ & $1.03 \pm 0.18$ & $0.82 \pm 0.01$ & $1.04 \pm 0.08$ & $1.11 \pm 0.09$ & $1.13 \pm 0.07$ & $1.15 \pm 0.06$ & $1.22 \pm 0.05$ \\
Porosity (\%) & $63.4 \pm 0.9$ & $59.6 \pm 2.8$ & $60.5 \pm 6.2$ & $67.6 \pm 0.6$ & $60.9 \pm 1.0$ & $58.7 \pm 4.6$ & $56.5 \pm 4.4$ & $59.5 \pm 1.0$ & $51.1 \pm 2.2$ \\
Sand \% & $76.12 \pm 7.32$ & $74.17 \pm 4.16$ & $73.84 \pm 1.57$ & $69.16 \pm 2.26$ & $69.89 \pm 2.73$ & $72.88 \pm 3.51$ & $75.76 \pm 2.90$ & $73.62 \pm 1.32$ & $71.11 \pm 1.58$ \\
Silt \% & $9.76 \pm 6.21$ & $7.37 \pm 5.74$ & $9.02 \pm 1.56$ & $10.6 \pm 2.86$ & $7.07 \pm 1.45$ & $7.89 \pm 0.14$ & $10.79 \pm 2.80$ & $10.02 \pm 1.63$ & $10.82 \pm 2.64$ \\
Clay \% & $14.12 \pm 1.66$ & $18.46 \pm 1.63$ & $17.14 \pm 1.57$ & $20.23 \pm 1.31$ & $23.03 \pm 1.32$ & $23.53 \pm 10.92$ & $13.46 \pm 2.67$ & $16.37 \pm 2.60$ & $18.07 \pm 3.24$ \\
Organic matter (\%) & $19.08 \pm 1.6$ & $15.47 \pm 1.11$ & $12.4 \pm 0.39$ & $16.12 \pm 1.1$ & $11.81 \pm 2.99$ & $10.4 \pm 0.8$ & $11.09 \pm 0.38$ & $10.03 \pm 0.29$ & $9.12 \pm 0.42$ \\
\hline
\end{tabular}



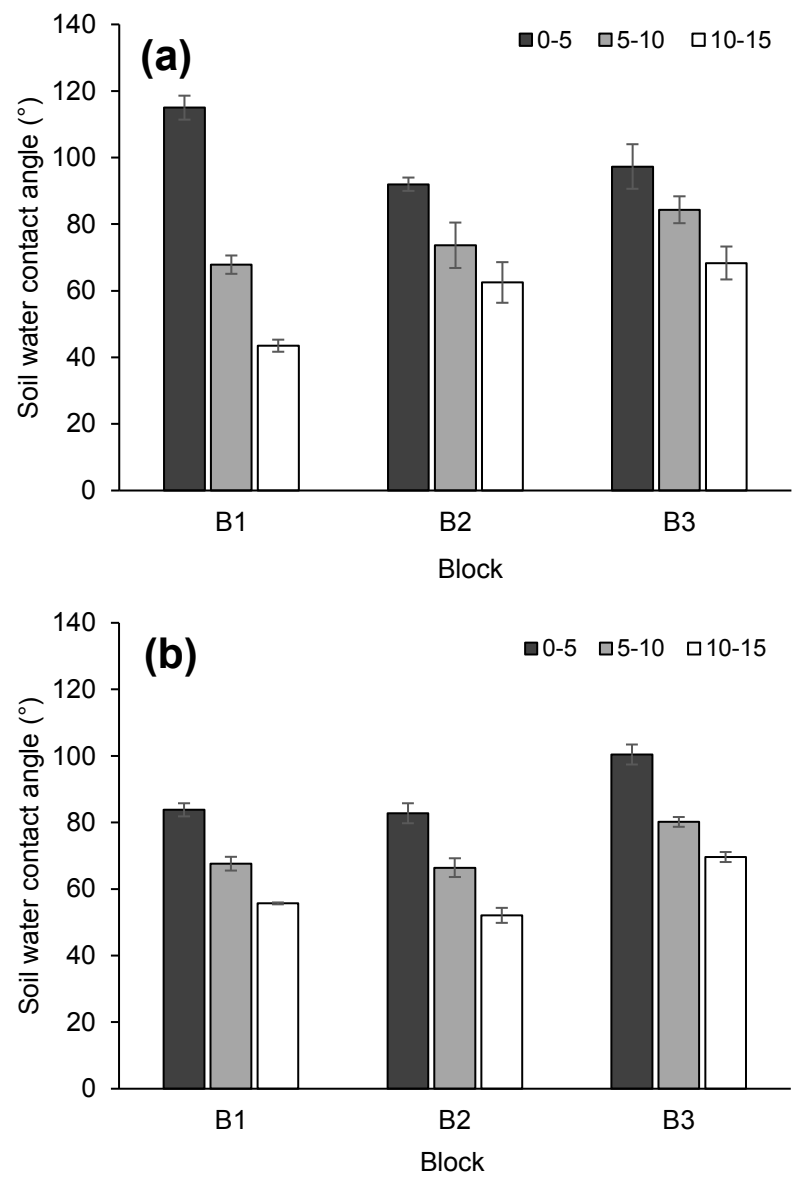

Fig. 4. The degree of water repellency in eucalyptus and pine plantation forest soils as measured by soil-water contact angle.

\section{Water entry value}

Fig. 5 presents the water entry values of the eucalyptus and pine forest soils. The water entry values of eucalyptus forest soils showed significantly high values than those of pine forest, except in B3 soils. It was clear that the water entry values of all the soils can be closely related to the water repellent conditions on the surface soils. As presented in Fig. 6, soil-water contact angle showed positive logarithmic correlation $\left(\mathrm{R}^{2}=0.66\right)$ to the water entry values. Liyanage and Leelamanie (2016) observed similar results in soils treated with hydrophobic casuarina leaf litter. Lee et al. (2015) observed similar results, and reported that water entry pressure increased with increasing water repellency in an artificially-prepared water-repellent silty soil. The increasing hydrophobicity of soil tend to increase the air encapsulation within the soil during the intake of water, which is known to reduce the rates of water intake by increasing the pressure required for the water entry of the repellent soils (Liyanage and Leelamanie, 2016; Sullivan, 1990). As explained by Letey et al. (2000), the water entry pressure is a function of both soil-water contact angle and the pore radius. Theoretically, a need of positive pressure arises to force water entry into the soil when the soil-water contact angles exceed $90^{\circ}$. This justifies the positive correlation between the water entry values and the soil-water contact angle (Bauters et al., 2000). With positive water entry values in water repellent soils, a ponding depth would be required to induce water entry into soils (Letey, 2001; Wang et al., 2000). High water entry values predict the potential risks of soil erosion, where building up of required ponding depths for water intake is difficult due to various reasons such

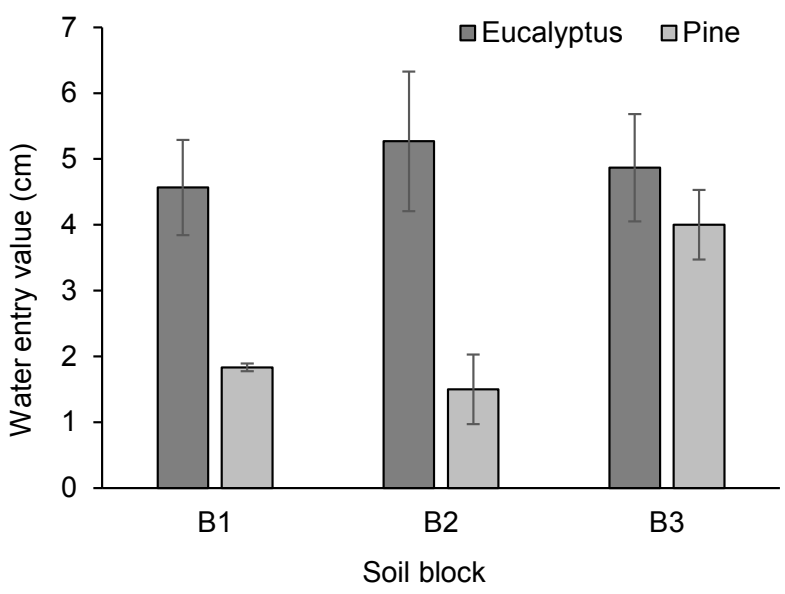

Fig. 5. Water entry values of the eucalyptus and pine forest soils.

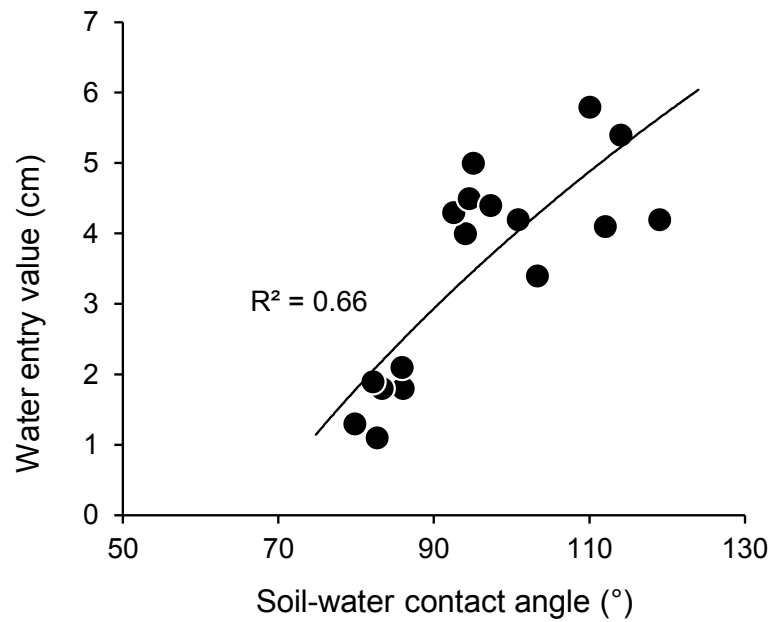

Fig. 6. Relation of soil-water contact angle to the water entry values of the eucalyptus and pine forest soils.

as high steepness of the slopes, which is characteristic in the study-sites of the present research.

\section{Social impacts as revealed by questionnaire based survey}

The responses of the people living in the surrounding areas of the two plantation forests on the availability of water for their domestic purposes, changes in water level in their household wells, and experience in drying up of artesian wells and water resources at present condition when compared with the situation in 1980-1990 are presented in Fig. 7. Results showed that about $90 \%$ the selected people living in both Diyathalawa and Haputale areas neighboring the eucalyptus and pine plantation forests, expressed that availability of water for domestic purposes at present is poor (response: 'worse') compared with the situation in 1990 (Fig.7a), and 10\% expressed no difference (response: 'no change') in the availability of water. Considering the response of the people, Wilcoxon sign rank test revealed a statistically significant $(\mathrm{p}<0.05)$ level of water scarcity conditions compared to the past in both areas.

About $85 \%$ of the interviewed people in Diyathalawa area (neighboring eucalyptus forest) and $88 \%$ in Haputale area (neighboring pine forest), claimed that they have experienced decreases in water levels in their groundwater wells compared with the past (Fig. 7b). Wilcoxon sign rank test revealed 

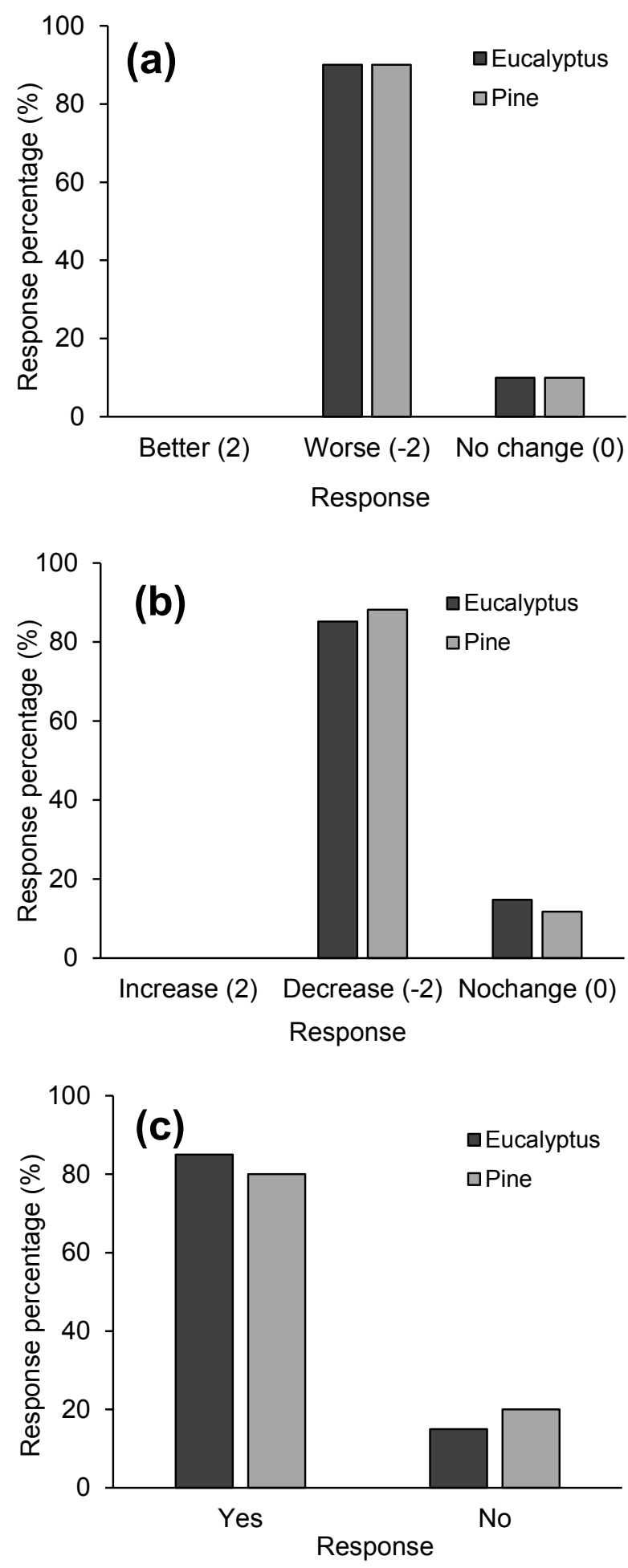

Fig. 7. The responses of the people living in the surrounding areas of the two plantation forests on (a) the availability of water for their domestic purposes, (b) changes in water level in their household wells, and (c) experience in drying up of fountains and water resources at present compared with the past (1980-1990).

significant decreases in groundwater levels in both Diyathalawa and Haputale areas.

Based on the results, $85 \%$ of the people living in the Diyathalawa area, $80 \%$ of the people living in the Haputale area have experienced drying up of artesian wells and water resources, which they have used in the past (Fig. 7c).
Results of the questionnaire based survey revealed that the people living in the surrounding areas of eucalyptus and pine forests have experiences in lowering groundwater levels and water scarcity conditions compared with the past. The groundwater level and natural water resources are highly important parameters for the people living in both areas as the people are accustomed to the use of groundwater wells as well as artesian wells and other natural water resources for their domestic purposes. The survey further revealed that the majority of the people are considering the introducing of these exotic species as the cause of initiating the water scarcity conditions. However, no person living in the area had any knowledge on water repellent conditions. People believed that the deep root systems in these exotic species withdraw water from deeper layers resulting in water scarcity conditions.

\section{Groundwater levels through modeling}

Changes in depth to the groundwater level from the surface in Diyathalawa and Haputale areas, respectively related with eucalyptus and pine plantation forests, from 1980 to 2018 as estimated through modelling using LST and NDVI thematic maps are presented in Fig. 8. The depth to the water level in groundwater wells in both Diyathalawa and Haputale areas showed exponential increases during the period from 1980 to 2018, revealing a gradual decrease in the groundwater levels. The standard deviations of the curves for eucalyptus was $1.227(\mathrm{~m})$ and that of pine was $1.356(\mathrm{~m})$.

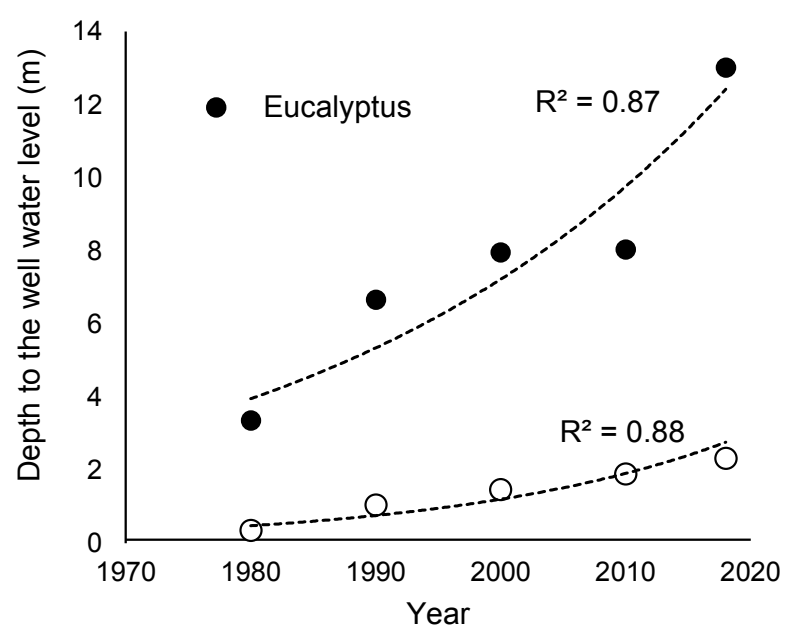

Fig. 8. Changes in depth to the groundwater level from the surface in Haputale and Diyathalawa areas from 1980 to 2018.

The reduction of groundwater level was apparently low in the Haputhale area, where the pine plantation is located, compared to the Diyathalawa area where eucalyptus plantation is located. In addition, dense and extremely water-repellent litter cover under these plantations might play an important role in assisting the overland flow, reducing the groundwater recharge. The results further revealed that the changes in groundwater level were very low in 1980s. The exponential trend of lowering the groundwater table hints on more pronounced water scarcity conditions in the future. The results of the present study revealed lowered water movements in the soil matrix as well as uneven distribution of water in the profile related to extreme water-repellent conditions observed on the soil surfaces of both pine and eucalyptus plantation forest soils. 


\section{Relation of water repellency to groundwater levels}

Results clearly revealed that soils of both lands covered by eucalyptus and pine plantation forests are showing water repellent conditions. Water repellent condition as well as the water entry values are significantly high compared with eucalyptus soils (Figs. 3, 4, 5). Water entry values revealed that for the entry of water from the surface, eucalyptus soils would require a ponding depth of 4.6-5.3 cm, whereas the pine soils would require a ponding depth of $1.5-4.0 \mathrm{~cm}$. Considering the topography, especially the slopes, of the study sites, it was clear that achieving these ponding depths would be difficult. For eucalyptus forest, attaining a ponding depth of above $4.5 \mathrm{~cm}$ would be almost impossible.

Modelling results revealed that the groundwater levels in the area of the eucalyptus forest diminished more dramatically, whereas the decline in the area of the pine forest was comparatively low. It was clear from the results that the groundwater recharge in the eucalyptus land was in a worse state compared with that in the pine forest land, suggesting endangered groundwater recharge in the highly hydrophobic eucalyptus land. Even with water repellent nature on the surface soils, presence of preferential flow paths in pine soils considered to be a possible process that supported groundwater recharging process.

\section{CONCLUSIONS}

The tested eucalyptus and pine forest soils showed very high water repellent levels on the surface. From the two soils, eucalyptus soils showed highly hydrophobic conditions. Considering the sloping landscape of the both areas, the surface runoff can be expected to become excessive. This would be the reason for the abundance of evidence of topsoil erosion in the area, which was more prominent in steeper slopes. Furthermore, achieving high ponding depths required for water entry would be difficult in these forested areas, more specifically in eucalyptus soils.

The modelling with remotely sensed thematic maps confirms that the groundwater levels in both areas, where the pine and eucalyptus plantations were located, has decreased exponentially over the time. Decline in the groundwater levels in the pine forest area was comparatively low, suggesting the presence of a successful process of groundwater recharge. Presence of preferential flow paths is considered to be a possible process for the groundwater recharge.

It was clear that the eucalyptus and pine vegetation have created unfavorable circumstances in regard with water entry and groundwater recharge. Proper attention from the responsible authorities will be essential to prevent the adverse impacts of on groundwater resource that can be considered as caused by introducing the exotic plant species, although the initial objective of introducing these plant species was to protect lands from degradation.

Acknowledgements. This work was financially supported by the University Grants Commission (UGC) Block grant for strengthening research [RU/PG-R/16/01].

\section{Conflicts of interest}

As the authors of the manuscript, herewith we confirm that the study has not received any funds from interested parties, except for the UGC Block grant [RU/PG-R/16/01] and that there are no conflicts of interest in any manner.

\section{REFERENCES}

Adane, Z., Nasta, P., Gates., J.B., 2017. Links between soil hydrophobicity and groundwater recharge under plantations in a sandy grassland setting, Nebraska Sand Hills, USA. Forest Science, 63, 4, 388-401. https://doi.org/10.5849/FS-2016-137

Alagna, V., Iovino, M., Bagarello, V., Mataix-Solera, J., Lichner, L., 2017. Application of minidisk infiltrometer to estimate water repellency in Mediterranean pine forest soils. Journal of Hydrology and Hydromechanics, 65, 3, 254-263. https://doi.org/10.1515/johh-2017-0009

Bachmann, J., Ellies, A., Hartge, K.H., 2000. Development and application of a new sessile drop contact angle method to assess soil water repellency. Journal of Hydrology, 231, 6675. https://doi.org/10.1016/S0022-1694(00)00184-0

Badía-Villas, D., González-Pérez, J.A., Aznar, J.M., ArjonaGracia, B., Martí-Dalmau, C., 2014. Changes in water repellency, aggregation and organic matter of a mollic horizon burned in laboratory: soil depth affected by fire. Geoderma, 213, 400-407. https://doi.org/10.1016/j.geoderma.2013.08.038

Bauters, T.W., Steenhuis, T.S., Parlange, J.Y., DiCarlo, D.A., 1998. Preferential flow in water-repellent sands. Soil Science Society of America Journal, 62, 5, 1185-1190. https://doi.org/10.2136/sssaj1998.03615995006200050005x

Bauters, T.W.J., Steenhuis, T.S., DiCarlo, D.A., Nieber, J.L., Dekker, L.W., Ritsema, C.J., Parlange, J.Y., Haverkamp, R., 2000. Physics of water repellent soils. Journal of Hydrology, 231, 233-243. https://doi.org/10.1016/S00221694(00)00197-9

Benito, E., Varela, E., Rodríguez-Alleres, M., 2019. Persistence of water repellency in coarse-textured soils under various types of forests in NW Spain. Journal of Hydrology and Hydromechanics, 67, 2, 129-134. https://doi.org/10.2478/johh2018-0038

Blake, G.R., Hartge, K.H., 1986a. Bulk density. In: Klute, A. (Ed.): Methods of Soil Analysis. Part 1: Physical and Mineralogical Methods. 2nd Ed. Soil Science Society of America: Madison, WI., pp. 363-375. https://doi.org/10.2136/sssabookser5.1.2ed.c13

Blake, G.R., Hartge, K.H., 1986b. Particle Density. In: Klute, A. (Ed.): Methods of Soil Analysis. Part 1: Physical and Mineralogical Methods. 2nd Ed. Soil Science Society of America: Madison, WI., pp. 377-382. https://doi.org/10.2136/sssabookser5.1.2ed.c14

Bouyoucos, G.J., 1962. Hydrometer method improved for making particle size analyses of soils 1. Agronomy Journal, 54, 5, 464-465. https://doi.org/10.2134/agronj1962. $00021962005400050028 \mathrm{x}$

Brunner, P., Franssen, H.J.H., Kgotlhang, L., Bauer-Gottwein, P., Kinzelbach, W., 2007. How can remote sensing contribute in groundwater modeling? Hydrogeology journal, 15, 1, 5-18. https://doi.org/10.1007/s10040-006-0127-z

Contreras, S., Cantón, Y., Solé-Benet, A., 2008. Sieving crusts and macrofaunal activity control soil water repellency in semiarid environments: evidences from SE Spain. Geoderma, 145, 3-4, 252-258. https://doi.org/10.1016/j.geoderma.2008.03.019

Doerr, S.H., Shakesby, R.A., Walsh, R.P., 1996. Soil hydrophobicity variations with depth and particle size fraction in burned and unburned Eucalyptus globulus and Pinus pinaster forest terrain in the Agueda Basin, Portugal. Catena, 27, 1, 25-47. https://doi.org/10.1016/0341-8162(96)00007-0

Doerr, S.H., Thomas, A.D., 2000. The role of soil moisture in controlling water repellency: new evidence from forest soils 
in Portugal. Journal of Hydrology, 231, 134-147. https://doi.org/10.1016/S0022-1694(00)00190-6

Doerr, S.H., Woods, S.W., Martin, D.A., Casimiro, M., 2009. 'Natural background' soil water repellency in conifer forests of the north-western USA: its prediction and relationship to wildfire occurrence. Journal of Hydrology, 371, 1-4, 12-21. https://doi.org/10.1016/j.jhydrol.2009.03.011

ESRI, 2017. ArcGIS-Desktop ArcMap: Release 10.4.1. Redlands, CA: Environmental Systems Research Institute.

Fér, M., Kodešová, R., 2012. Estimating hydraulic conductivities of the soil aggregates and their clay-organic coatings using numerical inversion of capillary rise data. Journal of Hydrology, 468, 229-240. https://doi.org/10.1016/j.jhydrol.2012.08.037

Fér, M., Leue, M., Kodešová, R., Gerke, H.H., Ellerbrock, R.H., 2016. Droplet infiltration dynamics and soil wettability related to soil organic matter of soil aggregate coatings and interiors. Journal of Hydrology and Hydromechanics, 64, 2, 111-120. https://doi.org/10.1515/johh-2016-0021

Flores-Mangual, M.L., Lowery, B., Bockheim, J.G., Pagliari, P.H., Scharenbroch, B., 2013. Hydrophobicity of Sparta sand under different vegetation types in the Lower Wisconsin River Valley. Soil Science Society of America Journal, 77, 5, 1506-1516. https://doi.org/10.2136/sssaj2012.0343

Gerke, H.H., Köhne, J.M., 2002. Estimating hydraulic properties of soil aggregate skins from sorptivity and water retention. Soil Science Society of America Journal, 66(1), 26-36. https://doi.org/10.2136/sssaj2002.2600

Giordano, M., 2009. Global groundwater? Issues and solutions. Annual Review of Environment and Resources, 34, 153-178. https://doi.org/10.1146/annurev.environ.030308.100251

Imeson, A.C., Verstraten, J.M., Van Mulligen, E.J., Sevink, J., 1992. The effects of fire and water repellency on infiltration and runoff under Mediterranean type forest. Catena, 19(3-4), 345-361. https://doi.org/10.1016/0341-8162(92)90008-Y

Iovino, M., Pekárová, P., Hallett, P.D., Pekár, J., Lichner, L., Mataix-Solera, J., Alagna, V., Walsh, R., Raffan, A., Schacht, K., Rodný, M., 2018. Extent and persistence of soil water repellency induced by pines in different geographic regions. Journal of Hydrology and Hydromechanics, 66, 4, 360-368. https://doi.org/10.2478/johh-2018-0024

Kajiura, M., Etori, Y., Tange, T., 2012. Water condition control of in situ soil water repellency: an observational study from a hillslope in a Japanese humid-temperate forest. Hydrological Processes, 26, 20, 3070-3078. https://doi.org/10.1002/hyp.8310

Kobayashi, M., Shimizu, T., 2007. Soil water repellency in a Japanese cypress plantation restricts increases in soil water storage during rainfall events. Hydrological Processes: An International Journal, 21, 17, 2356-2364. https://doi.org/10.1002/hyp.6754

Lee, C., Yang, H.J., Yun, T.S., Choi, Y., Yang, S., 2015. Water-entry pressure and friction angle in an artificially synthesized water-repellent silty soil. Vadose Zone Journal, 14, 4. https://doi.org/10.2136/vzj2014.08.0106

Leelamanie, D.A.L., 2016. Occurrence and distribution of water repellency in size fractionated coastal dune sand in Sri Lanka under Casuarina shelterbelt. Catena, 142, 206-212. https://doi.org/10.1016/j.catena.2016.03.026

Leelamanie, D.A.L., Karube, J., Yoshida, A., 2008. Characterizing water repellency indices: Contact angle and water drop penetration time of hydrophobized sand. Soil Science \& Plant Nutrition, 54, 2, 179-187. https://doi.org/10.1111/j.1747-0765.2007.00232.x
Leelamanie, D.A.L., Liyanage, T.D.P., Piyaruwan, H.I.G.S., 2016. Occurrence and Distribution of Water Repellency in soils under Exotic Plantation Forests in Sri Lanka. 13th Academic Sessions, University of Ruhuna, March 02, 2016. ISSN: 2362-0412

Leelamanie, D.A.L., Nishiwaki, J., 2019. Water repellency in Japanese coniferous forest soils as affected by drying temperature and moisture. Biologia, 74, 2, 127-137. https://doi.org/10.2478/s11756-018-0157-8

Letey, J., 2001. Causes and consequences of fire-induced soil water repellency. Hydrological Processes 15, 15, 28672875. https://doi.org/10.1002/hyp.378

Letey, J., Carrillo, M.L.K., Pang, X.P., 2000. Approaches to characterize the degree of water repellency. Journal of Hydrology, 231, $61-65$. https://doi.org/10.1016/S00221694(00)00183-9

Lichner, L.U., Hallett, P.D., Feeney, D.S., Duugová, O., Šír, M., Tesar̆, M., 2007. Field measurement of soil water repellency and its impact on water flow under different vegetation. Biologia, 62, 5, 537-541. https://doi.org/10.2478/s11756-0070106-4

Lichner, L., Capuliak, J., Zhukova, N., Holko, L., Czachor, H., Kollár, J., 2013. Pines influence hydrophysical parameters and water flow in a sandy soil. Biologia, 68, 6, 1104-1108. https://doi.org/10.2478/s11756-013-0254-7

Liyanage, T.D.P., Leelamanie, D.A.L., 2016. Influence of organic manure amendments on water repellency, water entry value, and water retention of soil samples from a tropical Ultisol. Journal of Hydrology and Hydromechanics, 64, 2, 160-166. https://doi: 10.1515/johh-2016-0025

McKissock, I., Gilkes, R.J., Harper, R.J., Carter, D.J., 1998. Relationships of water repellency to soil properties for different spatial scales of study. Soil Research. 36, 3, 495-508. https://doi.org/10.1071/S97071.

National Atlas of Sri Lanka, 2007. Second Edition, Survey Department of Sri Lanka. Colombo, Sri Lanka.

Pan, S.B., Wang, Z., Su, Q., Sun, T., Zhang, Y., 2008. Groundwater level monitoring model using multi-temporal images in arid region of northwest China. The International Archives of the Photogrammetry, Remote Sensing and Spatial Information Sciences, 37, 745-750.

Rao, N.S., Chakradhar, G.K.J., Srinivas, V., 2001. Identification of groundwater potential zones using remote sensing techniques in and around Guntur town, Andhra Pradesh, India. Journal of the Indian Society of Remote Sensing, 29, 69-78. https://doi.org/10.1007/BF02989916

Rodríguez-Alleres, M., Benito, E., de Blas, E., 2007. Extent and persistence of water repellency in north-western Spanish soils. Hydrological Processes: An International Journal, 21, 17, 2291-2299. https://doi.org/10.1002/hyp.6761

Santos, J.M., Verheijen, F.G., Tavares Wahren, F., Wahren, A., Feger, K.H., Bernard-Jannin, L., Rial-Rivas, M.E., Keizer, J.J., Nunes, J.P., 2016. Soil water repellency dynamics in pine and eucalypt plantations in Portugal-a high-resolution time series. Land Degradation \& Development, 27, 5, 13341343. https://doi.org/10.1002/ldr.2251

Schumacher, B.A., 2002. Methods for the determination of total organic carbon (TOC) in soils and sediments. Ecological Risk Assessment Support Center Office of Research and Development US. Environmental Protection Agency, 25 p.

Şen, Z., 2015. Applied Drought Modeling, Prediction, and Mitigation. Chapter 6: Climate change, droughts, and water resources. Elsevier, pp. 321-391. https://doi.org/10.1016/B978-0-12-802176-7.00006-7 
Senanayake, I.P., Dissanayake, D.M.D.O.K., Mayadunna, B.B., Weerasekera, W.L., 2016. An approach to delineate groundwater recharge potential sites in Ambalantota, Sri Lanka using GIS techniques. Geoscience Frontiers, 7, 115124. https://doi.org/10.1016/j.gsf.2015.03.002

Siteur, K., Mao, J., Nierop, K.G., Rietkerk, M., Dekker, S.C., Eppinga, M.B., 2016. Soil water repellency: a potential driver of vegetation dynamics in coastal dunes. Ecosystems, 19, 7, 1210-1224. https://doi.org/10.1007/s10021-016-9995-9

Soil Survey Staff, 2014. Keys to Soil Taxonomy. 12th ed. USDA-Natural Resources Conservation Service, Washington, DC.

Sullivan, L.A., 1990. Soil organic matter, air encapsulation and water-stable aggregation. Journal of Soil Science 41, 3, 529534. https://doi.org/10.1111/j.1365-2389.1990.tb00084.x

Vogelmann, E.S., Reichert, J.M., Reinert, D.J., Mentges, M.I., Vieira, D.A., de Barros, C.A.P., Fasinmirin, J.T., 2010. Water repellency in soils of humid subtropical climate of Rio Grande do Sul, Brazil. Soil and Tillage Research, 110, 1, 126-133. https://doi.org/10.1016/j.still.2010.07.006

Wahl, N.A., Bens, O., Schäfer, B., Hüttl, R.F., 2003. Impact of changes in land-use management on soil hydraulic properties: hydraulic conductivity, water repellency and water retention. Physics and Chemistry of the Earth, Parts A/B/C, 28, 33-36, 1377-1387. https://doi.org/10.1016/j.pce.2003.09.012
Wallis, M.G., Horne, D.J., McAuliffe, K.W., 1990. A study of water repellency and its amelioration in a yellow-brown sand: 1. Severity of water repellency and the effects of wetting and abrasion. New Zealand Journal of Agricultural Research, 33, 1, 139-144. https://doi.org/10.1080/00288233.1990.10430670

Wang, Z., Wu, L., Wu, Q.J., 2000. Water-entry value as an alternative indicator of soil water-repellency and wettability. Journal of Hydrology, 231, 76-83. https://doi.org/10.1016/S0022-1694(00)00185-2

Woche, S.K., Goebel, M.-O., Kirkham, M.B., Horton, R., Van der Ploeg, R.R., Bachmann, J., 2005. Contact angle of soils as affected by depth, texture, and land management. European Journal of Soil Science, 56, 2, 239-251. https://doi.org/10.1111/j.1365-2389.2004.00664.x

Ziogas, A.K., Dekker, L.W., Oostindie, K., Ritsema, C.J., 2005. Soil water repellency in north-eastern Greece with adverse effects of drying on the persistence. Soil Research, 43, 3, 281-289. https://doi.org/10.1071/SR04087

Zubair, L., Ropelewski, C.F., 2006. The strengthening relationship between ENSO and northeast monsoon rainfall over Sri Lanka and southern India. Journal of Climate, 19, 8, 15671575. https://doi.org/10.1175/JCLI3670.1

Received 19 April 2020 Accepted 17 July 2020 